\title{
The Effect of Cyanides on the Gill Colour of Fish.
}

\author{
By
}

\author{
R. Bassindale, B. A. Southgate and F. T. K. Pentelow, \\ Tees Survey, Middlesbrough.
}

\section{INTRODUCTION.}

In the course of an investigation into the causes of death of migrating salmon and sea trout smolts in the estuary of the River Tees, it was found, by chemical methods, that the main toxic constituent of the Estuary waters was cyanide, and that this was almost entirely responsible for the mortality.* During the survey attempts were made to determine the nature of the toxic substances concerned from the appearance of dead or dying smolts picked up in the Estuary.

In the spring of 1930 some thousands of dead smolts found on the estuary banks were examined, the fish being opened, and the macroscopic appearance of the organs noted. Their condition varied so widely, partly owing to the fact that the smolts could not always be collected immediately after their death, that no evidence of the nature of the lethal factor was obtained.

It was observed that, in cases where fish were poisoned in the Laboratory by exposure to solutions of cyanides, the gills became considerably brighter in colour than those of normal fish. This brightening is due to the arterial condition of the blood caused by the inhibition by cyanide of the action of the oxidase responsible for the transference of oxygen from the blood to the tissues. The change in colour in the gills of yearling rainbow trout (Salmo irideus Gibb.) brought about by cyanide poisoning was measured quantitatively by matching the gill colour of normal and dying fish against a graded colour chart. The method of preparation and calibration of this chart are described on page 675 . The chart consisted of a series of eight colours ranging from bright red (Colour No. 2) to dark crimson (Colour No. 16) : intermediate colours could be judged, giving a series of fifteen shades in all.

\section{EXPERIMENTAL.}

The principal conditions which may adversely affect fish-life in the Tees Estuary are the presence of cyanides (which are of preponderating importance), sewage, "tar acids" and possibly naphthalene, and a

* Southgate, B. A., Pentelow, F. T. K., and Bassindale, R. Biochem. J., XXVI, No. 2, pp. 273-284, 1932 . 
deficiency of dissolved oxygen. Experiments were carried out in which the changes in the gill colour of rainbow trout, and later of sea trout smolts (Salmo trutta L.), brought about by these factors were observed.

\section{TABLE I.}

The Change of Gill Colour of Rainbow Trout in a Solution of KCN Equivalent to 0.017 GM. (CN) PER 100 LITREs.

No. of fish before poisoning

\begin{tabular}{cccccccc}
5 & \multicolumn{4}{c}{$\begin{array}{c}\text { Colour No. } \\
\text { Average }\end{array}$} \\
& 6 & 7 & 8 & 9 & 10 & $\begin{array}{c}\text { Aill Colour } \\
\text { No. }\end{array}$ \\
& & & 2 & 11 & 3 & 9 \\
& 6 & 7 & & & & 6 \\
& & 3 & 7 & 4 & 1 & 8 \\
& & & 4 & 5 & 3 & 1 & 8
\end{tabular}

* 1 died,

\section{TABLE II.}

Change of Gill Colour of Fish During Poisoning. An Increase in the Gill Colour No. Indicates a Darkening of Colour.

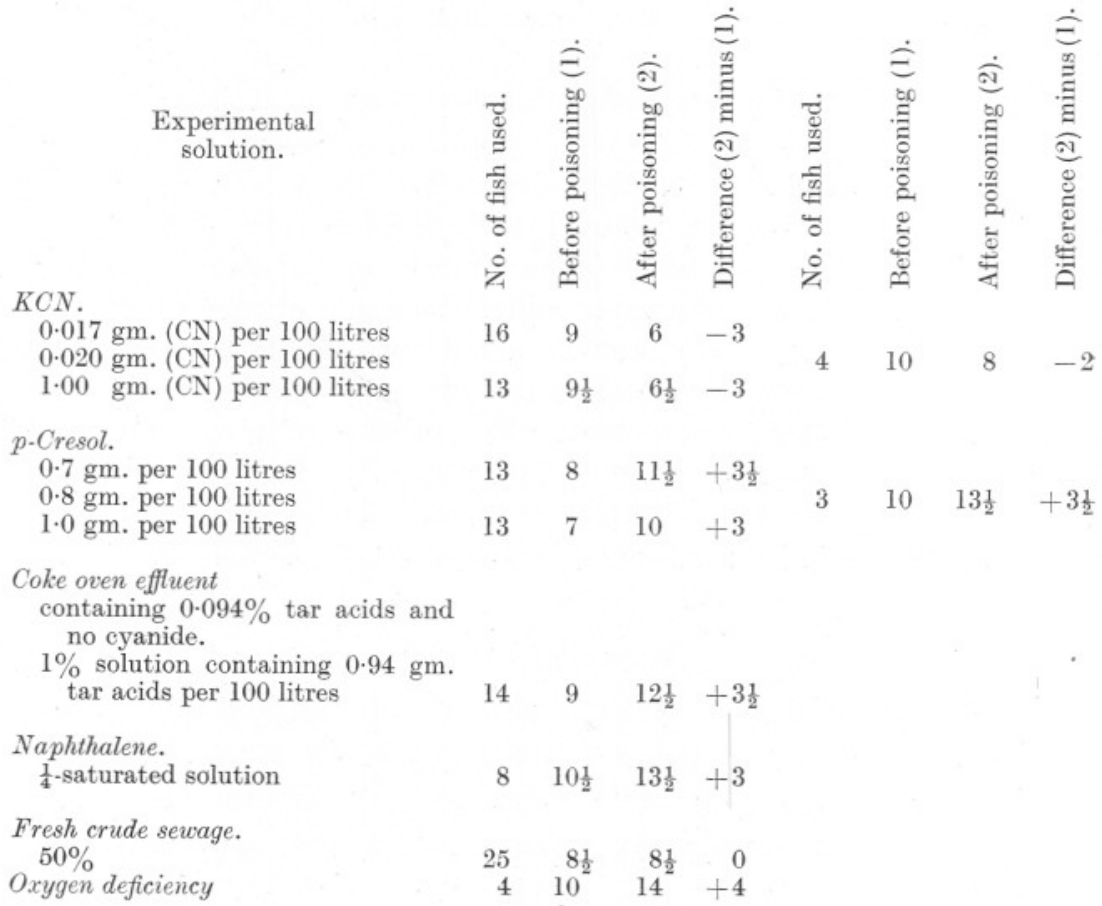

Rainbow Trout.
Average

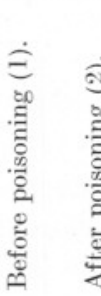

穴当

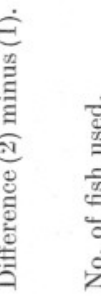

Sea Trout Smolts. Average

Gill Colours.

\footnotetext{
00 litres

$0.020 \mathrm{gm}$. (CN) per 100 litres

$1.00 \mathrm{gm}$. (CN) per 100 litres
}

-Cresol.

$0 \cdot 7 \mathrm{gm}$. per 100 litres

$0.8 \mathrm{gm}$. per 100 litre

oke oven effluent

no cyanide. $\%$ solution containing $0.94 \mathrm{gm}$. tar acids per 100 litres

aphthalene.

Fresh crude sewage.

Oxygen deficiency 
In a typical experiment, the gill colours of about twelve normal fish were determined, after which they were exposed to an experimental solution. When at least half the fish had turned over on their side, they were removed, their gill colours were again observed, and they were allowed to recover in fresh water, further observations being made during the period of recovery. The results of a typical experiment are shown in Table I.

The whole of the results obtained are summarised in Table II.

Only in the case of cyanide was there any brightening of the gill colour, a marked darkening occurring during the other two types of poisoning most likely to be met with in the Estuary, that is by oxygen deficiency or by "tar acids" (represented in one of the series of experiments by p-cresol).

Since cyanides, which cause a brightening of gill colour, and tar acids, which cause a darkening, are both constituents of certain industrial effluents, and are found together in the waters of the Estuary of the Tees, some experiments were carried out to determine whether the brightening of the one was neutralised by the darkening due to the other (Table III).

TABLE III.

Change in Gill Colour of Fish in Mixtures of Poisons. An Increase in the Gill Colour No. Indicates a Darkening of. Gill Colour.

(1) $K C N$,

\begin{tabular}{|c|c|c|c|c|c|c|c|c|}
\hline & & $\begin{array}{l}\text { inbo } \\
\text { Ave } \\
\text { xill C }\end{array}$ & $\begin{array}{l}\text { Trout } \\
\text { ge } \\
\text { ours. }\end{array}$ & & & $\begin{array}{r}\text { Sea ' } \\
\text { Ave } \\
\text { Gill C }\end{array}$ & & \\
\hline $\begin{array}{l}\text { Experimental } \\
\text { solution. }\end{array}$ & 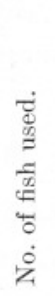 & 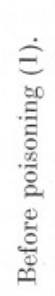 & 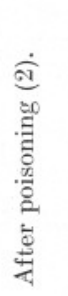 & 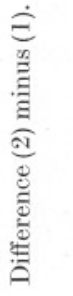 & 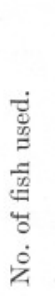 & 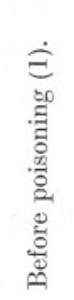 & 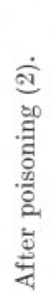 & 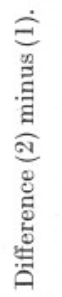 \\
\hline $\begin{array}{l}\text { gm. (CN) per } 100 \text { litres } \\
\text {. p-cresol per } 100 \text { litres }\end{array}$ & & & & & 3 & 12 & $8 \frac{1}{2}$ & $3 \frac{1}{2}$ \\
\hline $\begin{array}{l}\text { gm. (CN) per } 100 \text { litres } \\
\text { m. p-cresol per } 100 \text { litres }\end{array}$ & 12 & $8 \frac{1}{2}$ & $7 \frac{1}{2}$ & -1 & 3 & 11 & 8 & -3 \\
\hline $\begin{array}{l}n \text { effluent. } \\
\text { lution } \\
\text { contains } \\
\text { gm. (CN) per } 100 \text { litres } \\
\text { gm. Tar Acids per } 100 \\
\text { s. }\end{array}$ & 14 & 9 & $7 \frac{1}{2}$ & $-1 \frac{1}{2}$ & & & & \\
\hline
\end{tabular}


In the Tees Estuary the concentration of (CN) found by analysis does not usually exceed $0.02 \mathrm{gm}$. per 100 litres and that of tar acids $0.05 \mathrm{gm}$. per 100 litres. Even when the concentration of tar acid is twenty times that of $(\mathrm{CN})$, as in Experiment 1 of Table III, the brightening due to the cyanide is well marked. In Experiment 2, the concentrations of p-cresol and $\mathrm{KCN}$ used were of equal toxicity to rainbow trout. The industrial wastes discharged into the Tees Estuary consist mainly of two types of coke oven effluent. The change in gill colour brought about by one type, which owes its toxicity to tar acids, is recorded in Table II, and that due to the other type, the main toxic constituent of which is cyanide, is recorded in Table III. In neither of these cases did any other substance interfere with the characteristic gill colour change of the main toxic constituent. The data for sea trout smolts are not so complete as those for rainbow trout owing to the difficulty of keeping the smolts, but since the reaction of the two species to the solutions in which they were tested is similar, it is reasonable to suppose that it would also be similar for other substances.

\section{The Gill Colour of Salmon and Sea Trout Smolts Found Dying in the Tees Estuary.}

During the annual seaward migration of smolts in 1931, numbers of smolts of both sea trout and salmon (Salmo salar L.) were picked up in a dying condition in the Estuary, and their gill colours were compared with the colours of the standard chart. Only fish which were obviously alive and which were taken from the water were used. Some smolts were allowed to recover in freshwater tanks, after which the gill colours of the normal fish were recorded. The results obtained are given in Table IV.

\section{TABLE IV.}

The Gill Colour of Salmon and Sea Trout Smolts Dying in the Tees Estuary.

No. of smolts from which gill colour

Salmon smolts. Sea Trout smolts. records were taken Normal. Dying.

Normal. Dying.

Average gill colour

The gill colour of the dying fish was, in both cases, brighter than that of the normal fish, the average difference being 4.0 units in the case of salmon and 4.6 in the case of sea trout smolts. These results indicated that the smolts were dying from cyanide poisoning, a conclusion which was borne out by chemical observations. 


\section{The Gill Colour Scale.}

Eight colours were prepared by mixing three solutions of coloured inks (Winsor and Newton's Mandarin Waterproof) in various proportions. Details of the colour mixtures used are given below :-

Solution A. Scarlet ink, 3 vols. Distilled water, 1 vol.

Solution B. Ultramarine ink, $1 \cdot 7$ vols. Vermilion, 20 vols. Scarlet, 20 vols.

Solution C. Ultramarine ink, 3 vols. Brown, 2 vols. Distilled water, 4 vols.

\section{TABLE V.}

$\begin{array}{cccc}\text { Colour No. } & \begin{array}{c}\text { Solution A. } \\ \text { vols. }\end{array} & \begin{array}{c}\text { Solution B. } \\ \text { vols. }\end{array} & \begin{array}{c}\text { Solution C. } \\ \text { vols. }\end{array} \\ 2 & 8 & 1 & 0 \\ 4 & 6 & 3 & 0 \\ 6 & 4 & 5 & 0 \\ 8 & 3 & 6 & \frac{1}{2} \\ 10 & 1 & 8 & 2 \\ 12 & 0 & 9 & 4 \\ 14 & 0 & 9 & 6 \\ 16 & 0 & 9 & 9\end{array}$

Strips of Whatman's No. 1 filter paper were soaked in these solutions, excess ink being immediately removed with blotting-paper. The colours referred to in Table $\mathrm{V}$ are those of the rough side of the filter paper. An analysis of the colours of the standard chart, made with a Lovibond Tintometer, modified for use with reflected light, is given in Table VI.

\section{TABLE VI.}

\begin{tabular}{|c|c|c|c|}
\hline Gill Colour & \multicolumn{3}{|c|}{ Lovibond Tintometer Units. } \\
\hline Scale No. & Red. & Yellow. & Blue. \\
\hline 2 & $15 \cdot 8$ & 1.5 & 0 \\
\hline 4 & $15 \cdot 3$ & 1.5 & 0 \\
\hline 6 & $14 \cdot 2$ & $1 \cdot 9$ & 0 \\
\hline 8 & $12 \cdot 8$ & $1 \cdot 9$ & $0 \cdot 3$ \\
\hline 10 & $11 \cdot 0$ & $2 \cdot 5$ & $1 \cdot 3$ \\
\hline 12 & $9 \cdot 5$ & $2 \cdot 5$ & $2 \cdot 6$ \\
\hline 14 & $8 \cdot 9$ & $2 \cdot 8$ & $3 \cdot 4$ \\
\hline 16 & $6 \cdot 0$ & $2 \cdot 8$ & $4 \cdot 0$ \\
\hline
\end{tabular}

NEWTSERIES.-VOL. XVIII. NO. 2. JANUARY, 1933. 


\section{SUMMARY.}

1. The changes brought about in the colour of the gills of rainbow trout and sea trout smolts by various poisons are described.

2. Cyanide causes a marked brightening, whilst phenolic substances, dissolved oxygen deficiency and naphthalene bring about a darkening of the gill colour. Fresh, untreated sewage has no effect.

3. The gill colour of smolts dying in the Tees Estuary was brighter than normal, indicating cyanide poisoning. This conclusion was confirmed by chemical methods.

The work described in this paper was carried out as part of the programme of the Water Pollution Research Board of the Department of Scientific and Industrial Research and is published by permission of the Department. We are indebted to Mr. N. Strafford, of the British Dyestuffs Corporation, Ltd., for calibration of the standard colour chart by the Lovibond Tintometer. 